\title{
ITS Design Priority at Large Bus Terminal in Indonesia in Supporting Sustainable Transportation
}

\author{
Anastasia Caroline Sutandi 'Wimpy Santosa, Felix Hidayat, and Aini Nur Zahiyah
}

\begin{abstract}
Intelligent Transportation Systems (ITS) is an important part of sustainable transportation. Implementation of ITS at large bus terminal is needed in order to increase the service quality to the passenger and encourage people to use public transportation. Unfortunately, not all of large bus terminal in large cities in Indonesia have implemented ITS yet. The aim of this study is to identify availability of ITS implementation at the large bus terminal, to evaluate whether the ITS system has fulfil the ITS standard in Indonesia, and to recommend ITS design to be implemented based on the needs, priority, and local condition at the large bus terminal. Implementation of ITS is compulsory but priority is also important based on limited support of financial, officer's capability, and commitment of the authority are the challenges. Case study is carried out at Cicaheum large bus terminal type-A in Bandung, Indonesia. Standard used is regulation of Ministry of in Indonesia, and number 132 year 2015 regarding information technology standard, including safety aspect, security aspect, reliability aspect, convenience aspect, easily aspect, and equality aspect of ITS implementation. Data collection used is direct observation of ITS implementation at Cicaheum large bus terminal in Bandung, Indonesia, questionnaire and interview with the bus terminal authority regarding the ITS implementation. Analysis method is Simple Additive Weighting. Result indicated that ITS design priority is CCTV application, topping bus ticket, automatic door bar at terminal gate, availability of facility of disable person, digital facility sign, traffic sign development, on time bus schedule, passenger information in the terminal regarding bus delay, and online/ mobile ticketing. Since these part of ITS is implemented, then based on existing condition of the large bus terminal, other part of ITS can also be implemented in the future.
\end{abstract}

Index Terms - ITS design priority, large bus terminal, large city, sustainable transportation, Indonesia.

\section{INTRODUCTION}

$\mathrm{S}_{\text {ustainable transportation is the transportation system that }}$ $\mathbf{S}_{\text {provides road facilities with many transportation modes lead }}$

to minimum using of non renewable resources and limited using of renewable resources including using Intelligent Transportation Systems (ITS) so that the future generation will not bear new problems $[1,2]$.

A.C. Sutandi is with the Civil Engineering Department, Parahyangan Catholic University, Bandung, West Java, Indonesia (e-mail: caroline@unpar.ac.id)

W. Santosa is with the Civil Engineering Department, Parahyangan Catholic University, Bandung, West Java, Indonesia
ITS is the system of advance technology to enhance efficiency and capacity of existing road infrastructure, increase road safety, improve convenience and ease of travel, and then will reduce traffic congestion [3, 4]. ITS implementation at large bus terminal in large city in Indonesia is important. This condition will encourage people to come to bus terminal, use public transportation, and then will reduce traffic congestion. Large bus terminal is chosen because this terminal is the terminal with most ready to implement advance technology like ITS. Since ITS systems consist of so many parts that cannot be implemented all soon in one time, priority of implementation of part of ITS at the large bus terminal is needed.

Cicaheum bus terminal is one of large bus terminals in Indonesia. This is a type-A (large bus terminal) in the third largest city in Indonesia named Bandung. Nevertheless, the implementation of ITS at this large bus terminal to has better serve to passenger is minim and only in the beginning level. Therefore, ITS with priority implementation because of existing condition of large bus terminal is crucial to do.

The aim of this study is to identify availability of ITS implementation at large bus terminal, to evaluate whether the ITS system has fulfil the ITS standard in Indonesia, and to recommend ITS design to be implemented based on the priority, the needs, and existing condition at the large bus terminal. It is hoped that in the future, the recommended ITS design can also be implemented at other bus terminals in Indonesia, by taking into account of their existing condition.

\section{ITS AT LARGE BUS TERMINAL IN INDONESIA}

Bus terminal is the pool location that used to manage arriving and departing bus public transportation to serve passenger, goods, and transit mode, and minimize delay time. In order to minimize delay time, therefore bus schedule, ticketing, and passenger information have to be provided integrated [5-8].

There are three types of bus terminal in Indonesia. They are type-A bus terminal (large bus terminal), type-B bus terminal, and type-C bus terminal as presented in Table 1 . 


\section{Methodology}

Research methodology used in this study to provide ITS design priority at large bus terminal in Indonesia in supporting sustainable transportation. The method used in analysis is Simple Additive Weighting Method.

TABLE I

TYPES OF BUS TERMINAL IN INDONESIA $[5,9,10,11]$

\begin{tabular}{cccc}
\hline $\begin{array}{c}\text { Terminal } \\
\text { type }\end{array}$ & $\begin{array}{c}\text { Number of } \\
\text { terminal }\end{array}$ & Serving activity & $\begin{array}{c}\text { Terminal } \\
\text { authority }\end{array}$ \\
\hline A & 143 & $\begin{array}{c}\text { Trip between } \\
\text { cities, } \\
\text { provinces, } \\
\text { countries }\end{array}$ & $\begin{array}{c}\text { Land } \\
\text { Transport } \\
\text { Management } \\
\text { Agency - } \\
\text { Province } \\
\text { Level }\end{array}$ \\
B & 325 & $\begin{array}{c}\text { Trip between } \\
\text { cities in the } \\
\text { same } \\
\text { provinces }\end{array}$ & \\
\hline & & \\
\end{tabular}

\begin{tabular}{cc} 
C $355 \quad \begin{array}{c}\text { Trip in the } \\
\text { city or } \\
\text { village }\end{array}$ \\
\hline
\end{tabular}

Simple Additive Weighting Method is a common multiattribute decision making method with a number alternatives wherein each alternative has many criteria. Multi-attribute decision making method is a process of determining the decision criteria, congruence of alternatives in each criteria, and normalization of the matrix, in order to determine sequence of the alternatives based on preference value.

The process is presented in equation (1) up to equation (5). Normalization is needed to make each alternative free of uncertainly or fuzzy. Sequence of the alternatives is presented from alternative with the highest value to alternative with the lowest value. Alternative with the highest value is represents the most relevant alternative to be implemented based on the existing condition.

TABLE II

EXISTING FACILITIES AT CICAHEUM LARGE BUS TERMINAL IN BANDUNG, INDONESIA

\begin{tabular}{|c|c|}
\hline Aspects & Availability $(\sqrt{ })$ and information \\
\hline \multicolumn{2}{|l|}{ Safety aspects } \\
\hline Pedestrian way & $\sqrt{ }$ for one person \\
\hline Safety furniture & $\sqrt{ }$ sign, marking, lighting \\
\hline Evacuation sign & --- \\
\hline Fire extinguisher & $\sqrt{ } 2$ fire extinguisher \\
\hline Health post & $\sqrt{ }$ \\
\hline Bus checking facility & --- \\
\hline Bus minor repair facility & --- \\
\hline \multicolumn{2}{|l|}{ Security aspect } \\
\hline Security complain facility & --- \\
\hline Security post & $\sqrt{ }$ \\
\hline CCTV & --- \\
\hline Security officer & $\sqrt{ } 12$ persons \\
\hline \multicolumn{2}{|l|}{ Reliability aspect } \\
\hline Arriving / departing schedule and bus tariff & $\sqrt{ }$ only for DAMRI bus \\
\hline Next bus schedule & --- \\
\hline Ticketing counter & $\sqrt{ }$ \\
\hline Control room & $\sqrt{ }$ to manage and control buses at terminal \\
\hline Checking post & $\sqrt{ } 2$ post at enter and exit terminal gate \\
\hline \multicolumn{2}{|l|}{ Convenience aspect } \\
\hline Waiting room & $\sqrt{ }$ room condition need to be improved \\
\hline Praying room & $\sqrt{ }$ good room condition \\
\hline Smoking room & $\sqrt{ }$ \\
\hline Reading room & --- \\
\hline Hot spot & $\sqrt{ }$ \\
\hline Toilet & $\sqrt{ } 2$ ladies room and 2 gents room \\
\hline Restaurant & $\sqrt{ }$ \\
\hline Janitor & $\sqrt{ }$ \\
\hline Drainage & $\sqrt{ }$ ditch and septic tank \\
\hline \multicolumn{2}{|l|}{ Easily aspect } \\
\hline Location of bus arriving and departing & $\sqrt{ }$ \\
\hline Passenger information about bus schedule & $\sqrt{ }$ \\
\hline Mobile charging facility & $\sqrt{ }$ limited access \\
\hline Aboard and alight facility to the bus & $\sqrt{ }$ \\
\hline Parking Area & $\sqrt{ }$ only for bus and motorcycle \\
\hline \multicolumn{2}{|l|}{ Equality aspect } \\
\hline Disable facility & --- \\
\hline
\end{tabular}



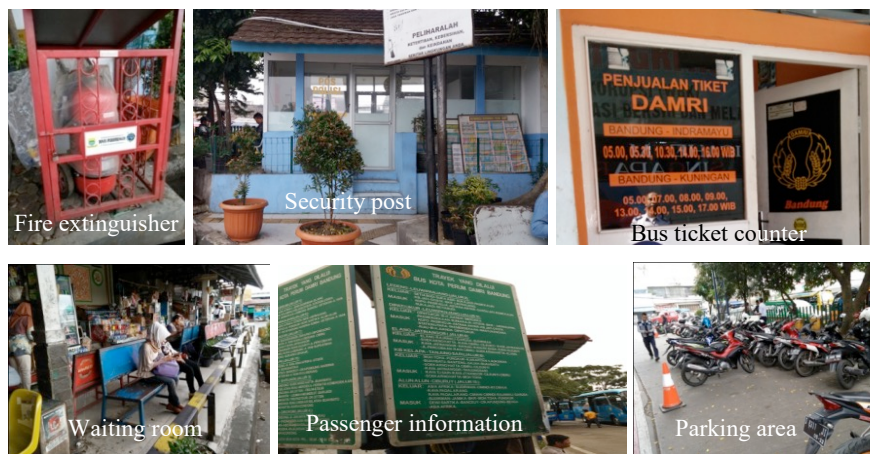

Fig. 1. Existing condition of facilities at Cicaheum large bus terminal in Bandung, Indonesia

While preference value is determined based on the opinion of decision maker, in this study, is bus terminal authority. This is the benefit of Simple Additive Weighting Method that has capability to determine preference value from highest value to lowest value and make decision maker easy to choose alternatives with priority to be implemented [12-14].

with:

$$
\begin{aligned}
A & =\left\{A_{i} \mid i=1,2, \ldots, n\right\} \\
C & =\left\{C_{j} \mid i=1,2, \ldots, n\right\} \\
X & =\left[\begin{array}{ccc}
x_{11} & \cdots & x_{1 n} \\
\vdots & \ddots & \vdots \\
x_{m 1} & \cdots & x_{m n}
\end{array}\right]
\end{aligned}
$$

$A$ : a number of alternatives

$C$ : criteria of each alternative

$X_{i j}$ : performance appraisal of alternative $\mathrm{i}$ with criteria $\mathrm{j}$ [12]

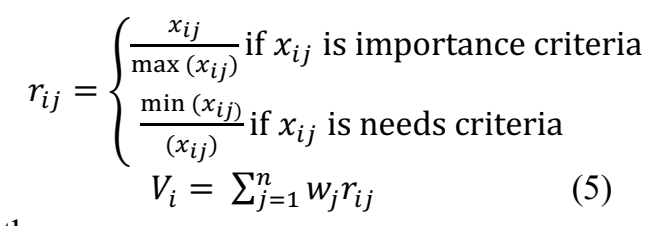

with:

$r_{i j}$ : normalized appraisal of alternative $A_{i}$ for criteria $C_{j}$

$\mathrm{V}_{\mathrm{i}}$ : preference value

$\mathrm{W}_{\mathrm{j}}$ : weigh factor

\section{Field Data ANd Analysis}

Field Data was collected in April 2017 and May 2017. Primary data is existing facilities of Cicaheum Bus Terminal, questionnaire and interview with the terminal authority. Questionnaire is regarding ITS implementation according to regulations in Indonesia. Secondary data is regarding Cicaheum Bus Terminal status.

The Cicaheum Bus Terminal is a type-A terminal/ large bus terminal at large city Bandung, Indonesia. It located on Ahmad Yani road, Kiaracondong, Bandung with area of $11,000 \mathrm{~m}^{2}$. Figure 2 presents the terminal and bus circulation at the terminal. The detail development of the terminal since year 1974 up to year 2017 is presented in Table 3.

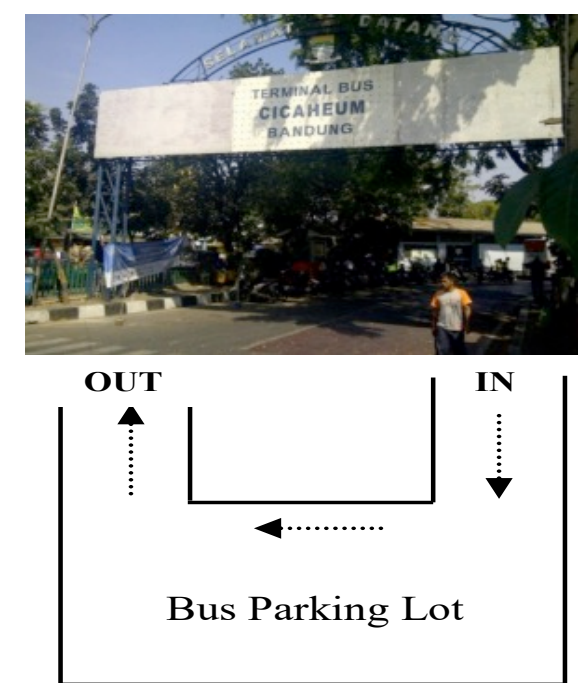

Fig. 2. Cicaheum bus terminal and bus circulation at the terminal, Bandung, Indonesia.

The existing facilities at Cicaheum large bus terminal in Bandung regarding the 6 aspects of ITS implementation have been presented earlier in Table 1. This condition is only the beginning of ITS implementation at the large bus terminal.

Furthermore, results of questionnaire to the terminal authority of Cicaheum large bus terminal in Bandung, Indonesia regarding level of importance and level of needs of ITS based on regulations in Indonesia is presented in Table 4. Likert scale from value 1 (the lowest value) to value 5 (the highest value) is used to describe the importance and the needs of ITS implementation.

ITS importance rate and ITS needs rate are use because ITS implementation in the large bus terminal is minim and at the beginning level, so that level of satisfaction as appraisal cannot be used in this study. Moreover, interview result with the terminal authority is the challenges in implementing ITS at the terminal i.e. limited support of financial, officer's capability, and commitment of the authority.

Result of questionnaire and interview with the terminal authority is presented in Table 4. Then the results are analysed using descriptive statistics and Simple Additive Weighting method. Analysis process using 5 questions in Simple Additive Weighting method is presented in Table 5. Analysis results of ITS needs to be implemented at Cicaheum large bus terminal in Bandung, Indonesia using Simple Additive Weighting method is presented in Table 6. Moreover, the analysis results are used in developing ITS design priority at large bus terminal in Indonesia in supporting sustainable transportation. 
TABLE III

DEVELOPMENT OF CiCAHEUM LARGE Bus TeRminal 1974- 2017.

\begin{tabular}{cl}
\hline Year & \multicolumn{1}{c}{ Development of Cicaheum bus terminal } \\
\hline 1974 & Building construction of Cicaheum bus terminal begin. \\
\hline 1975 & Operation of Cicaheum bus terminal begins with capacity of 70 buses. \\
\hline $1975-1986$ & Cicaheum bus terminal serves bus route between provinces and between cities in the same province. \\
\hline 1986 & Rehabilitation of Cicaheum bus terminal so that it has capacity of 300 buses. \\
\hline & $\begin{array}{l}\text { Cicaheum bus terminal serves 13 bus routes between provinces and between cities in the same } \\
\text { province, and also serves 1 bus route in Bandung city (DAMRI Trans Metro Bandung / TMB). } \\
\text { Cicaheum bus terminal capacity: } 98 \text { buses operates between provinces, 165 buses operates in the } \\
\text { same province, and 45 buses operates in Bandung city (DAMRI and TMB). }\end{array}$ \\
\hline
\end{tabular}

TABLE IV

DEVELOPMENT OF CiCAHEUM BUS TERMINAL 1974- 2017.

\begin{tabular}{cccc}
\hline No & ITS Alternative at Cicaheum large bus terminal based on & $\begin{array}{c}\text { Value of ITS } \\
\text { Importance Rate }\end{array}$ & $\begin{array}{c}\text { Value of ITS } \\
\text { Needs Rate }\end{array}$ \\
\hline 1 & Website development & 5 & 3 \\
\hline 2 & Traffic sign development & 5 & 4 \\
\hline 3 & Digital facility sign & 3 & 5 \\
\hline 4 & Online complain facility & 4 & 5 \\
\hline 5 & CCTV & 5 & 5 \\
\hline 6 & Digital passenger information & 5 & 3 \\
\hline 7 & Real time video of arriving and departing bus & 5 & 3 \\
\hline 8 & Bus schedule and bus route in internet & 3 & 3 \\
\hline 9 & On time bus schedule & 5 & 4 \\
\hline 10 & Passenger information regarding bus delay time at terminal & 5 & 4 \\
\hline 11 & Passenger information regarding bus delay time using sms & 4 & 3 \\
\hline 12 & Online / mobile ticketing & 5 & 4 \\
\hline 13 & Topping of TMB bus ticket & 5 & 5 \\
\hline 14 & Automatic door bar at terminal gate & 5 & 5 \\
\hline 15 & Availability of hot spot & 4 & 4 \\
\hline 16 & Availability of facility of disable person & 5 & 5 \\
\hline
\end{tabular}

TABLE V

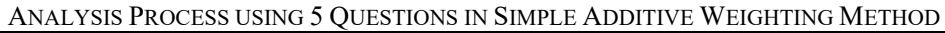

ITS Alternative $\left(\mathrm{A}_{1} \ldots \mathrm{A}_{16}\right)$

With $\mathrm{C}_{1}=$ importance rate $=1.00$ and $\mathrm{C}_{2}=$ needs rate $=1.50$

Performance Appraisal

\begin{tabular}{|c|c|c|c|c|c|c|}
\hline & \multirow{3}{*}{$\begin{array}{c}\text { ITS Alternative }\left(A_{1} \ldots A_{16}\right) \\
\text { With } C_{1}=\text { importance rate }=1.00 \\
\text { and } C_{2}=\text { needs rate }=1.50\end{array}$} & \multicolumn{4}{|c|}{ Performance Appraisal } & \multirow{3}{*}{$\begin{array}{l}\text { Performance } \\
\text { Value }\left(V_{i}\right)\end{array}$} \\
\hline & & \multicolumn{2}{|c|}{$\begin{array}{c}\text { Before } \\
\text { Normalization } \\
\end{array}$} & \multicolumn{2}{|c|}{$\begin{array}{c}\text { After } \\
\text { Normalization } \\
\end{array}$} & \\
\hline & & $\mathrm{r}_{1}$ & $\mathrm{r}_{2}$ & $\mathrm{r}_{1}$ & $\mathrm{R}_{2}$ & \\
\hline $\mathrm{A}_{1}$ & Website development & 5.00 & 3.00 & 1.00 & 0.60 & 3.08 \\
\hline $\mathrm{A}_{2}$ & Traffic sign development & 5.00 & 4.00 & 1.00 & 0.80 & 3.64 \\
\hline $\mathrm{A}_{3}$ & Digital facility sign & 3.00 & 5.00 & 0.60 & 1.00 & 3.64 \\
\hline $\mathrm{A}_{4}$ & Online complain facility & 5.00 & 5.00 & 0.80 & 0.80 & 3.36 \\
\hline $\mathrm{A}_{5}$ & CCTV & 5.00 & 5.00 & 1.00 & 1.00 & 4.20 \\
\hline $\mathrm{A}_{6}$ & Digital passenger information & 5.00 & 3.00 & 1.00 & 0.60 & 3.08 \\
\hline $\mathrm{A}_{7}$ & Real time video of arriving and departing bus & 5.00 & 3.00 & 1.00 & 0.60 & 3.08 \\
\hline A8 & Bus schedule and bus route in internet & 3.00 & 3.00 & 0.60 & 0.60 & 2.52 \\
\hline $\mathrm{A}_{9}$ & On time bus schedule & 5.00 & 4.00 & 1.00 & 0.80 & 3.64 \\
\hline $\mathrm{A}_{10}$ & $\begin{array}{l}\text { Passenger information regarding bus delay } \\
\text { time at terminal }\end{array}$ & 4.00 & 3.00 & 1.00 & 0.80 & 3.64 \\
\hline $\mathrm{A}_{11}$ & $\begin{array}{l}\text { Passenger information regarding bus delay } \\
\text { time using sms }\end{array}$ & 4.00 & 3.00 & 0.80 & 0.60 & 2.80 \\
\hline $\mathrm{A}_{12}$ & Online / mobile ticketing & 5.00 & 4.00 & 1.00 & 0.80 & 3.64 \\
\hline $\mathrm{A}_{13}$ & Topping of TMB bus ticket & 5.00 & 5.00 & 1.00 & 1.00 & 4.20 \\
\hline $\mathrm{A}_{14}$ & Automatic door bar at terminal gate & 5.00 & 5.00 & 1.00 & 1.00 & 4.20 \\
\hline $\mathrm{A}_{15}$ & Availability of hot spot & 4.00 & 4.00 & 0.80 & 0.80 & 3.36 \\
\hline $\mathrm{A}_{16}$ & Availability of facility of disable person & 5.00 & 5.00 & 1.00 & 1.00 & 4.20 \\
\hline
\end{tabular}




\section{ITS Design Priority at Large Bus Terminal in INDONESIA}

Additive Weighting method as presented in Table 6 then use to develop ITS design priority at large bus terminal in Indonesia in supporting sustainable transportation.

Implementation of ITS is compulsory but priority is also important based on limited support of financial, officer's capability, and commitment of the authority. These are the challenges. ITS facilities can be located inside or outside the terminal and will be controlled in the bus terminal management control. The ITS design priority is presented in Figure 5.

Analysis results of ITS implementation needs at Cicaheum large bus terminal in Bandung, Indonesia using Simple

TABLE VI

ANALysis RESUlt REGARDing OF ITS NEED to BE IMPLEMENTED AT CiCAHEUM LARGE Bus TERMINAL IN BANDUNG, INDONESIA USING SiMPLE ADDITIVE WEIGHTING METHOD (SAWM)

\begin{tabular}{|c|c|c|}
\hline Alternative & $\begin{array}{c}\text { Result of } \\
\text { SAWM }\end{array}$ & $\begin{array}{l}\text { Priority } \\
\text { Category }\end{array}$ \\
\hline CCTV application & 4.20 & \multirow{4}{*}{ I } \\
\hline Topping of TMB bus ticket & 4.20 & \\
\hline Automatic door bar at terminal gate & 4.20 & \\
\hline Availability of facility of disable person & 4.20 & \\
\hline Digital facility sign & 3.64 & \multirow{5}{*}{ II } \\
\hline Traffic sign development & 3.64 & \\
\hline On time bus schedule & 3.64 & \\
\hline Passenger information regarding bus delay time at terminal & 3.64 & \\
\hline Online / mobile ticketing & 3.64 & \\
\hline Online Complain facility & 3.36 & \multirow{2}{*}{ III } \\
\hline Availability of hotspot & 3.36 & \\
\hline Website development & 3.08 & \multirow{3}{*}{ IV } \\
\hline Digital passenger information & 3.08 & \\
\hline Real time video of arriving and departing bus & 3.08 & \\
\hline Passenger information regarding bus delay time using sms & 2.80 & $\mathrm{~V}$ \\
\hline Bus schedule and bus route in internet & 2.52 & VI \\
\hline
\end{tabular}

It can be seen in Table 6 that CCTV application, topping of TMB bus ticket, automatic door bar at terminal gate, and availability of facility of disable person are ITS alternatives that have the first priority to be implemented. The reason is because these indicators have to be fulfilled according to the regulation. In more detail, CCTV and automatic door bar at terminal gate have been applied earlier, but they are nor working at this time. Whereas bus schedule and bus route information through internet is the ITS alternative with the lowest priority because most of the passengers are at the middle and low income level and it is easier for them to get information direct from the bus terminal as usual.

ITS design priority in Figure 5 is developed with consideration of availability, condition, service standard, regulation, and priority of ITS implementation at bus terminal. Moreover, detail explanation regarding implementation of ITS design priority at the bus terminal is presented in Table 7. Since these part of ITS is implemented, then based on local condition of the large bus terminal, other part of ITS can also be implemented in the future.

\section{CONCLUSION}

Large bus terminal in large cities in Indonesia needs ITS to increase passenger service quality and encourage people to use public transportation in supporting sustainable transportation. Since ITS cannot be implemented soon and in one time, priority is needed according to existing challenges condition at large bus terminal i.e. limited support of financial, officer's capability, commitment of the authority and existing ITS implementation condition that only in the beginning level. ITS design priority is developed based on observation, questionnaire, and interview results with the terminal authority using Simple Additive Weighting method. The ITS design provided in this study is not advanced ITS, because the bus terminal existing conditions have not fulfilled the aspects required by regulation in Indonesia yet, but can be implemented soon. After implemented the simple ITS at large bus terminal, the next priority of ITS implementation can be applied at the future, in large bus terminal and at the other type bus terminal. 


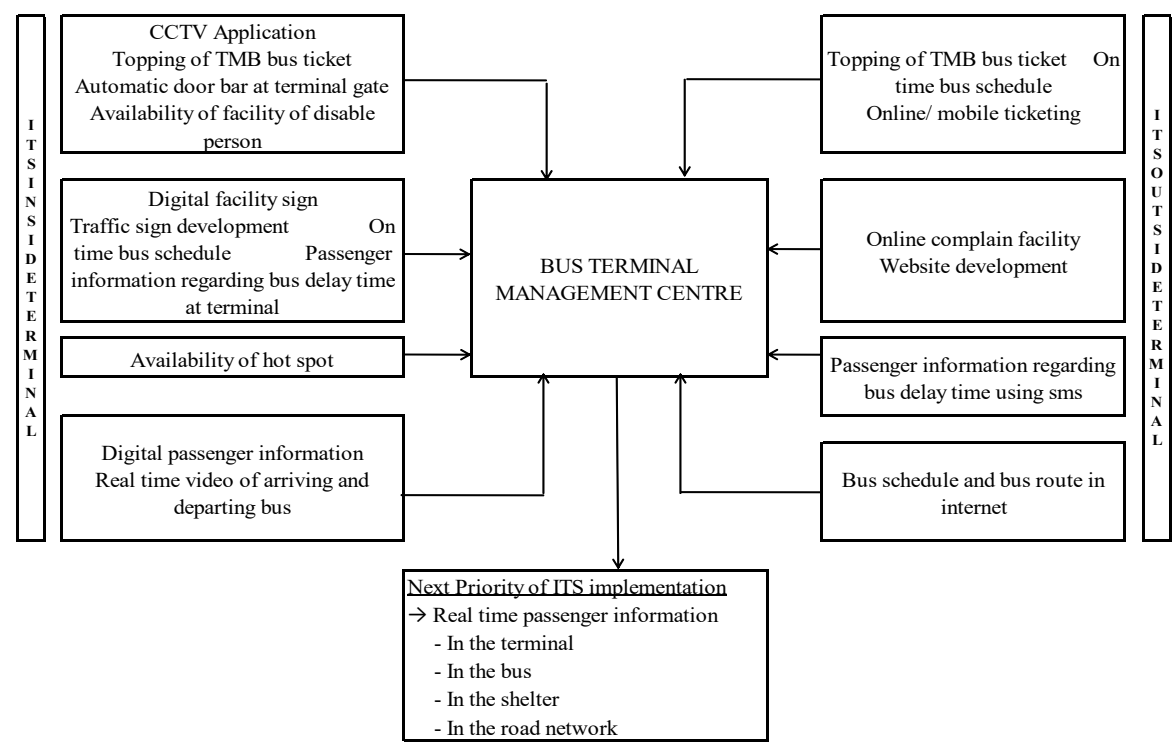

Fig. 5. ITS design priority at large bus terminal in Indonesia in supporting sustainable transportation

TABLE VII

EXPLANATION REGARDING IMPLEMENTATION OF ITS DESIGN PRIORITY AT THE BUS TERMINAL

\begin{tabular}{|c|c|c|c|c|}
\hline Alternative & $\begin{array}{l}\text { Priority } \\
\text { Category }\end{array}$ & Aspects & $\begin{array}{l}\text { Location Inside } \\
\text { (I) / Outside (O) } \\
\text { terminal }\end{array}$ & Explanation \\
\hline $\begin{array}{l}\text { CCTV application } \\
\text { Topping of TMB bus ticket } \\
\text { Automatic door bar at terminal } \\
\text { gate } \\
\text { Availability of facility of } \\
\text { disable person }\end{array}$ & I & $\begin{array}{l}\text { Security } \\
\text { Equality }\end{array}$ & $\begin{array}{c}\mathrm{I} \\
\mathrm{I} / \mathrm{O}\end{array}$ & $\begin{array}{l}\text { CCTV installed in waiting } \\
\text { room at enter and exit gate. } \\
\text { Automatic door bar at enter and } \\
\text { exit gate. } \\
\text { Facility for disable including } \\
\text { bus portable ramp. }\end{array}$ \\
\hline $\begin{array}{l}\text { Digital facility sign } \\
\text { Traffic sign development } \\
\text { On time bus schedule } \\
\text { Passenger information } \\
\text { regarding bus delay time at } \\
\text { terminal } \\
\text { Online / mobile ticketing }\end{array}$ & II & $\begin{array}{l}\text { Reliability } \\
\text { Safety } \\
\text { Reliability } \\
\text { Reliability }\end{array}$ & $\begin{array}{c}\mathrm{I} \\
\mathrm{I} \\
\mathrm{I} / \mathrm{O} \\
\mathrm{I}\end{array}$ & $\begin{array}{l}\text { Digital and traffic sign to } \\
\text { manage traffic bus circulation. } \\
\text { On bus time and on Time bus } \\
\text { schedule to give certainty to the } \\
\text { passengers. } \\
\text { Online / mobile ticketing can } \\
\text { use mobile application. }\end{array}$ \\
\hline $\begin{array}{l}\text { Online Complain facility } \\
\text { Availability of hotspot }\end{array}$ & III & $\begin{array}{c}\text { Reliability } \\
\text { Convenience }\end{array}$ & $\begin{array}{l}\mathrm{O} \\
\mathrm{I}\end{array}$ & $\begin{array}{l}\text { Online complain can use } \\
\text { mobile application. } \\
\text { Hot spot needs to cover entire } \\
\text { terminal area. }\end{array}$ \\
\hline $\begin{array}{l}\text { Website development } \\
\text { Digital passenger information } \\
\text { Real time video of arriving and } \\
\text { departing bus }\end{array}$ & IV & $\begin{array}{c}\text { Easily } \\
\text { Reliability } \\
\text { Reliability }\end{array}$ & $\begin{array}{l}\mathrm{O} \\
\mathrm{I}\end{array}$ & $\begin{array}{l}\text { Website to inform passenger. } \\
\text { Digital passenger information } \\
\text { and the real time video installed } \\
\text { in waiting room. }\end{array}$ \\
\hline $\begin{array}{l}\text { Passenger information } \\
\text { regarding bus delay time using } \\
\text { sms }\end{array}$ & V & Reliability & $\mathrm{O}$ & $\begin{array}{l}\text { Bus delay time information to } \\
\text { give certainty to the passengers. }\end{array}$ \\
\hline $\begin{array}{l}\text { Bus schedule and bus route in } \\
\text { internet }\end{array}$ & VI & Easily & $\mathrm{O}$ & $\begin{array}{l}\text { The information to make } \\
\text { passenger easy. }\end{array}$ \\
\hline
\end{tabular}

\section{ACKNOWLEDGEMENT}

Thank you to Direktorat Riset dan Pengabdian Masyarakat, Direktorat Jendral Penguatan Riset dan Pengembangan, Ministry of Research, Technology, and Higher Education, Republic of Indonesia for financial support of this study.

\section{REFERENCES}

[1] W.R. Black, "Sustainable Transportation - Problems and Solutions," the Guilford Press, A Division of Guilford
Publications, Inc, 72 Spring Street, New York, NY 10012, www.guilford.com, 2010.

[2] A.C. Sutandi, "ITS Impact On Traffic Congestion And Environmental Quality In Large Cities In Developing Countries," Proceeding of the Eastern Asia Society for Transportation Studies, Vol.7, 2009, ISBN: 1881 - 1132, P180 (Paper 180), Publisher Japan Science and Technology Information Aggregator, Electric, J-STAGE K-WING 6F, 2-1, Kojimachi 5 chome, Chiyoda-ku, Tokyo, 102-0083, Japan, 2009.

[3] A.C. Sutandi, "Advanced Traffic Control Systems, Performance Evaluation in a Developing Country," LAP 
LAMBERT Publishing GmbH \& Co. KG. Dudweiler Landstr, 99.66123, Saarbrucken, Germany. Phone +49 681 3720-310, fax +49 681 3720-3109, email info@Lap-publishing.com, ISBN 978-3-8433-5117-1, printed in USA, Amazone.com, 2010.

[4] University of Queensland, Short Course on ITS Advance Transport Technologies, 2001, 2001.

[5] Ministry of Transportation, Republic of Indonesia, Regulation of Ministry of Transportation Republic of Indonesia, number 40 year 2015 about Service Standard of Public Transport Terminal Operation, Jakarta, 2015.

[6] Ministry of Transportation, Republic of Indonesia, Regulation of Ministry of Transportation Republic of Indonesia, number 132 year 2015 about Operation of Land Transport Terminal, Jakarta, 2015.

[7] E.K. Morlok, "Pengantar Teknik dan Perencanaan". Jakarta: Erlangga book publisher, 2015.

[8] S. Grava, "Urban Transportations Systems". New York, NY: McGraw-Hill Education, 2002.

[9] Ministry of Transportation, Republic of Indonesia, Regulation of Ministry of Transportation Republic of Indonesia, number 25 year 2009 about Public Services, Jakarta, 2009.

[10] Badan Perencanaan dan Pembangunan Daerah, Masterplan Transportasi Kota Bandung 2031, Bandung, 2014.

[11] Pemerintah Kota Bandung, Peraturan Walikota Bandung Nomor 413 Tentang Pembentukan dan Susunan Organisasi Unit Pelaksana Teknis pada Lembaga Teknis Daerah dan Dinas Daerah di Lingkungan Pemerintah Kota Bandung, Bandung, 2010.

[12] Adriyendi, "Multi-Attribute Decision Making Using Simple Additive Weighting and Weighted Product in Food Choice," www version 2.1, (http://www.mecs-press.org/ijieeb/ijieeb-v7n6/IJIEEB-V7-N6-2.pdf, accessed in June 2017, 2015.

[13] A. Afshari, M. Mojahed, and R. M. Yusuff, "Simple Additive Weighting Approach to Personnel Selection Problem," International Journal of Innovation, Management and Technology, 1(5):511-515, 2010.

[14] K.S.S Anupama, S.S.Gowri, B.P. Rao, and P. Rajesh, "Application of MADM Algorithm to Network Selection," International Journal of Innovative, Instrumentation and Control Engineering, 3(6): 64-67, 2015. 